\title{
Effect of Air Flow on Emission of Smoldering Incense
}

\author{
T. T. Yang, ${ }^{1}$ C. C. Chen, ${ }^{2}$ J. M. Lin ${ }^{1}$
}

${ }^{1}$ Institute of Environmental Health, College of Public Health, National Taiwan

University, Room 1451, Number 1, Section 1, Jen-Ai Road, Taipei, Taiwan, Republic of China

${ }^{2}$ Institute of Occupational Medicine and Industrial Hygiene, College of Public

Health, National Taiwan University, Room 1451, Number 1, Section 1, Jen-Ai Road,

Taipei, Taiwan, Republic of China

Received: 30 May 2004/Accepted: 23 November 2004

Burning incense sticks as a religious ritual is common in Chinese society. It is part of the daily routine of about $50 \%$ of families in Taiwan. Epidemiological studies indicated that exposure to incense smoke might be related to the occurrence of lung cancer (MacLennan et al, 1977), childhood leukemia (Lowergard et al, 1987) and brain tumor (Preston-Martin et al, 1982). Ames test identified the mutagenic effect of the incense smoke (Sato et al, 1980; Rasmussen et al, 1987; Chang et al, 1997).

The smoldering of incense is regarded as an incomplete combustion of biomasses, and takes a relatively long time. It results in the production of gaseous carbon monoxide, carbon dioxide, nitrogen oxides, polycyclic aromatic hydrocarbons (PAHs), formaldehyde, volatile organic compounds (VOCs) and chemical-bearing particles (Schoental et al., 1967; Lin and Wang, 1994; Lin and Tang, 1994; Lin and Lee, 1998). The diameter of the submicrometer particles produced by incense smoke was less than $1 \mu \mathrm{m}$. Therefore, the submicrometer particles produced by the smoldering of incense do not only have a higher chance of penetrating the alveolar region of human lungs. Yet, their number concentration and surface area were higher, enabling them better to carry pollutant matter. The constituents of the incense stick and the conditions of incense combustion (airflow, temperature, humidity and oxygen content) both affect in determining the characteristics of incense smoke. This work tried to simulate the combustion of incense at home or in the temple, to elucidate the characteristics of submicrometer particles and gas pollutant produced by incense smoke in controlled air flow in an attempt to correct the indoor contamination caused by incense burning.

\section{MATERIALS AND METHODS}

The joss sticks used in this study consisted of incense powder and a bamboo stick. The incense powder was a mixture of three varieties of dried vegetation, Santalum album L., Machilus nanmu Hemsl and Pine oleoresin. The carbon, hydrogen and nitrogen contents in the joss stick were measured using an elemental analyzer (2400 CHN Elemental Analyzer, Perkin-Elmer, U.S.A.). The heat value was measured using an oxygen bomb calorimeter (1271 Oxygen Bomb Calorimeter, Parr Instrument Company, U.S.A.). 


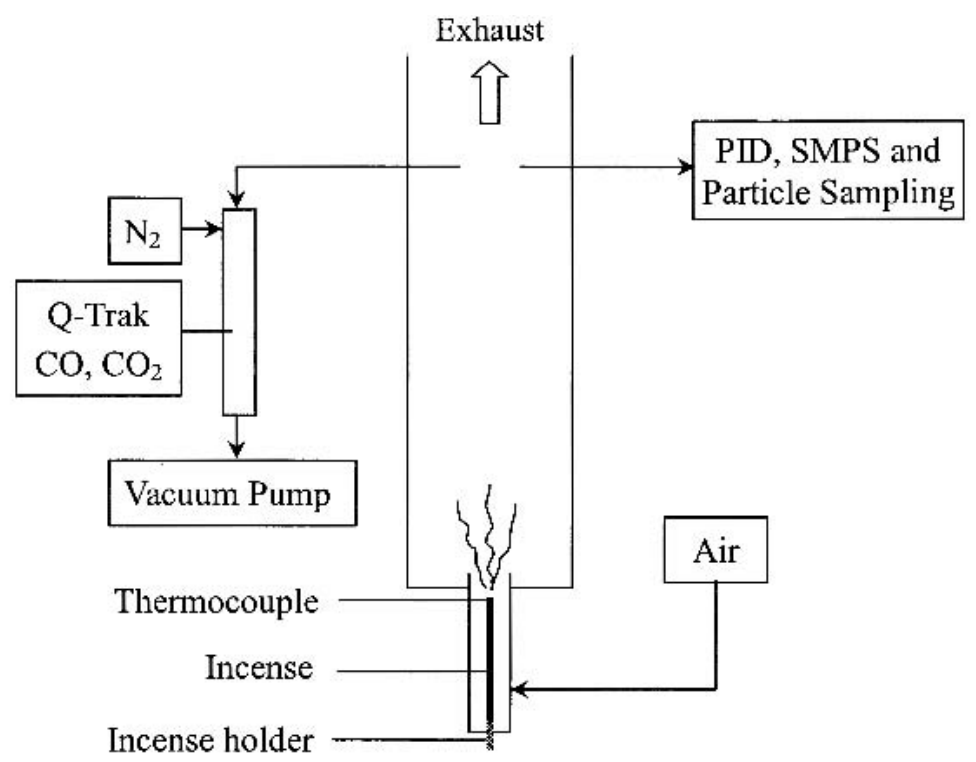

Figure 1. Incense combustion system.

A joss stick was ignited and inserted into an incense holder at the bottom of the smoldering chamber where the purified compressor air was supplied and regulated by mass flow controllers (Fig. 1). The surface temperature of the burning tip of an incense stick was monitored using a K-type thermocouple made of $79 \mu \mathrm{m}$ nickel-aluminum and nickel-chrome wires. The incense smoke was led into a $7.3 \mathrm{~L}$ test chamber in which a probe ( $1 / 4$-inch in diameter) for sampling particles was located $40 \mathrm{~cm}$ away from the bottom of the test chamber and $3.5 \mathrm{~cm}$ away from the wall. Before and after burning, an individual joss stick was weighed to determine the net loss of mass, enabling the incense-burning rate to be calculated.

Particles were counted and sized using a Scanning Mobility Particle Sizer (SMPS, Model 3934, TSI Inc., USA), which combined a differential mobility analyzer (DMA, Model 3071, TSI Inc.) with a condensation particle counter (CPC, Model 3022, TSI Inc.). The total particles were sampled with a quartz filter $(37 \mathrm{~mm}$, Pallgelman, U.S.A.) in a two-piece cassette at flow rate of $0.9 \sim 2 \mathrm{~L} / \mathrm{min}$ for ten minutes to determine mass concentration of particles. A $1.4 \mathrm{~L}$ dilution chamber was annexed to the test chamber to determine the concentration of carbon monoxide, and carbon dioxide (Fig. 1). The incense smoke was diluted with pure nitrogen ( $99.99 \%$, Shen Yi Gas Co., Taiwan) prior to it entered the dilution chamber. This step reduced the concentration of pollutants into the specified detectable ranges of $0-5000 \mathrm{ppm}$ for $\mathrm{CO}_{2}$ and $0-500 \mathrm{ppm}$ for $\mathrm{CO}$, of the real-time monitoring instruments. The Q-Trak ${ }^{\text {TM }}$ Indoor Air Quality Monitor (Model 8550/8551, TSI Inc., U.S.A.) measured the $\mathrm{CO}_{2}$ and $\mathrm{CO}$ concentrations with accuracy $\pm 3 \%$. The MiniRAE 2000 Portable VOC Monitor (RAE SYSTEMS Inc., USA) with specified range of $0-10000 \mathrm{ppm}$ and accuracy $\pm 10 \%$ measured the response of total VOCs 
with UV at $10 \mathrm{ev.} \mathrm{Both} \mathrm{zero} \mathrm{calibration} \mathrm{and} \mathrm{span} \mathrm{calibration} \mathrm{were} \mathrm{conducted} \mathrm{for}$ each instrument by following the manufacturers' instructions. For the responsive span calibration of the Q-Trak ${ }^{\mathrm{TM}}$, the reference CO (99.9\%, Sanfu Gas Co., Taiwan) and $\mathrm{CO}_{2}$ (99.99\%, Sanfu Gas Co., Taiwan) were diluted, using high pure nitrogen (99.9995\%, Sanfu Gas Co., Taiwan) to 395 ppm and $4050 \mathrm{ppm}$, respectively. And the standard isobutylene (100 ppm, RAE SYSTEMS Inc., USA) was used to calibrate the VOC Monitor.

The emission rates and emission factors of particles or gas were calculated using the conservation of mass, as follows.

$$
\mathrm{V} \times \frac{\mathrm{dCi}}{\mathrm{dt}}=\mathrm{R} \times \mathrm{E}_{\mathrm{f}}-\mathrm{Q} \times \mathrm{Ci}
$$

where $\mathrm{V}\left(\mathrm{m}^{3}\right)$ is the volume of the test chamber; $\mathrm{C}_{i}\left(\mathrm{mg} / \mathrm{m}^{3}\right.$ or particles $\left./ \mathrm{cm}^{3}\right)$ is the concentration of gas or particles at a given time; $\mathrm{R}(\mathrm{g} / \mathrm{hr})$ is the incense-burning rate; $\mathrm{E}_{f}(\mathrm{mg} / \mathrm{g}$ or particles $/ \mathrm{g})$ is the emission factor of each pollutant, and $\mathrm{Q}(5 \mathrm{~L} / \mathrm{min})$ is the air flow rate. In Eq. 1, $\mathrm{dCi} / \mathrm{dt}=0$ when each pollutant in the dilution chamber is in dynamic equilibrium, so the equation can be rewritten as follows;

$$
\mathrm{E}_{\mathrm{f}}=\frac{\mathrm{Q} \times \mathrm{C}}{\mathrm{R}}
$$

In Eq. 2, the emission rate was obtained by multiplying the flow rate by the concentration of pollutant and the emission factor, $E_{f}$, was the specific emission rate that was normalized to incense burning rate. The expression for the concentrations of gaseous pollutants was converted from $\mathrm{ppm}\left(\mathrm{v} / \mathrm{v}\right.$ at $25^{\circ} \mathrm{C}, 1 \mathrm{~atm}$.) to $\mathrm{mg} / \mathrm{m}^{3}$ based on the ideal gas law. In calculating the emission rate of total VOCs, the molecular weight of total VOCs was assumed to be $100 \mathrm{~g}$.

\section{RESULTS AND DISCUSSION}

The incense used in this study consisted of carbon, hydrogen, nitrogen, ash and water, with weight percentages of $43.59,5.4,0.61,7.72$ and $7.39 \%$, respectively. The heating value of the incense was $3934 \mathrm{Kcal} / \mathrm{Kg}$. The incense underwent smoldering combustion. The maximum temperature of the burning tip, in which the pooled coefficient of variation $\left(\mathrm{CV}_{\text {pooled }}\right)$ was $0.04\left(\mathrm{n}_{\text {total }}=3 \times 6\right)$, varied with the flow rate (Fig. 2). When the air flow rate was $1 \sim 5 \mathrm{~L} / \mathrm{min}$, the maximum temperature ranged from $328.2^{\circ} \mathrm{C}(\mathrm{n}=3, \mathrm{CV}=0.03)$ to $452.9^{\circ} \mathrm{C}(\mathrm{n}=3, \mathrm{CV}=0.02)$. When the air flow rate was $10 \sim 20 \mathrm{~L} / \mathrm{min}$, the maximum temperature reduced slowly from $253.0^{\circ} \mathrm{C}(\mathrm{n}=3, \mathrm{CV}=0.04)$ to $160.3^{\circ} \mathrm{C} \quad(\mathrm{n}=3, \mathrm{CV}=0.06)$. The burning rate increased with the air flow rate up to $15 \mathrm{~L} / \mathrm{min}$ at a temperature of $210.1^{\circ} \mathrm{C}$ $(n=3, C V=0.01)$, after which the burning rate decreased slowly. This result differed a little from that of the relationship between the burning rate and the inner temperature of foam obtained by Wang et al. (2003), who found that the burning rate was maximum at the maximum temperature. However, the results herein showed that the burning rate was maximum at a flow rate of $15 \mathrm{~L} / \mathrm{min}$, but not at maximum temperature, perhaps because the K-type thermocouple at high air flow rate, causing errors of measurement. 


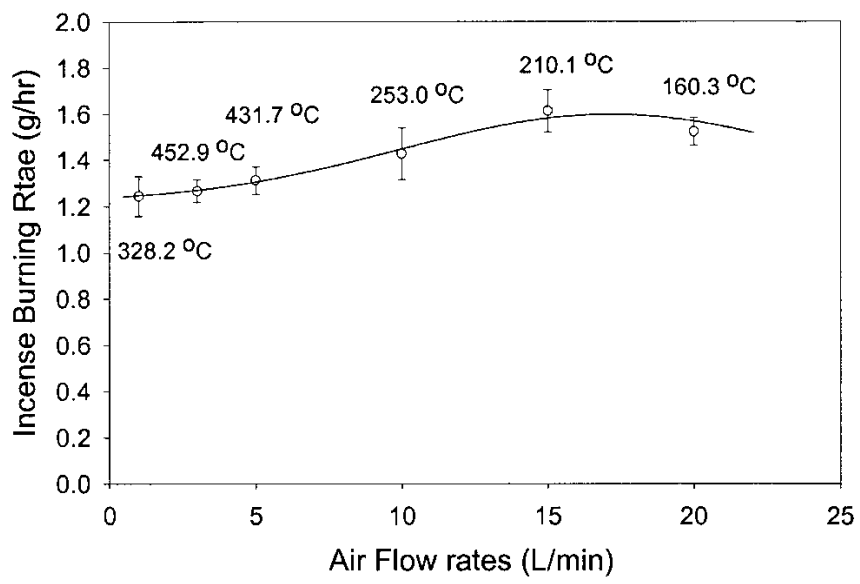

Figure 2. Burning rate and maximum temperature of burning tip at various air flow rates (Bar: mean \pm standard deviation).

The count median diameter shifted from 242 to $120 \mathrm{~nm}$ as the air flow rate increased (Fig. 3). Additionally, the number concentration, the emission rate and emission factor for particle with size less than $250 \mathrm{~nm}$ showed that these parameters all increased with the air flow rate increasing, for the following two reasons. Firstly, the retention time and the coagulation of the highly number concentration of particle from the burning incense decreased slowly in the test chamber as the air flow rate increased. Secondly, the organic compounds on the surface of the particle were likely vaporized.

Figure 4 reveals that when the air flow rate was in the range $1 \sim 20 \mathrm{~L} / \mathrm{min}$, the total number concentration, emission rate and emission factor increased linearly with the air flow rate. The number emission rate and emission factor ranged from $7.25 \times 10^{11}$ to $2.34 \times 10^{13} \# / \mathrm{hr}$ and from $5.98 \times 10^{11}$ to $1.53 \times 10^{13} \# / g$, respectively. The mass concentration declined with the air flow rate increasing. However, the emission rate and emission factor after increasing, remains constant as the air flow rates increased. The mass emission rate with $\mathrm{CV}_{\text {pooled }}=0.15(\mathrm{n}=3 \times 6)$ and emission factor with $\mathrm{CV}_{\text {pooled }}=0.13(\mathrm{n}=3 \times 6)$ ranged from $10.6 \mathrm{mg} / \mathrm{hr}(\mathrm{n}=3, \mathrm{CV}=0.23)$ to $72.1 \mathrm{mg} / \mathrm{hr}$ $(\mathrm{n}=3, \mathrm{CV}=0.19)$ and from $8.3 \mathrm{mg} / \mathrm{g}(\mathrm{n}=3, \mathrm{CV}=0.19)$ to $43.2 \mathrm{mg} / \mathrm{g}(\mathrm{n}=3, \mathrm{CV}=0.22)$, respectively. The volume concentration, emission rate and emission factor followed the same trend as the mass concentration against air flow rate. The volume emission rate and emission factors ranged from $2.06 \times 10^{19}$ to $5.32 \times 10^{19} \mathrm{~nm}^{3} / \mathrm{hr}$ and from $1.7 \times 10^{19}$ to $3.47 \times 10^{19} \mathrm{~nm}^{3} / \mathrm{g}$, respectively. Lee et al. (2004) constructed a large environmental chamber to characterize the emissions of air pollutants from traditional incense. The emission rates for PM2.5 and PM10 were 28.4 372.6 and $31.9 \sim 389.4 \mathrm{mg} / \mathrm{hr}$, respectively; the emission factor was 9.6 104 and 10.8 108.7 $\mathrm{mg} / \mathrm{g}$, respectively. Furthermore, Jetter et al. (2002) made a small chamber to improve the characterization of the emission of particulate matter from burning incense. The emission rates for PM2.5 and PM10 were 7.0 108 and 7.4 100 


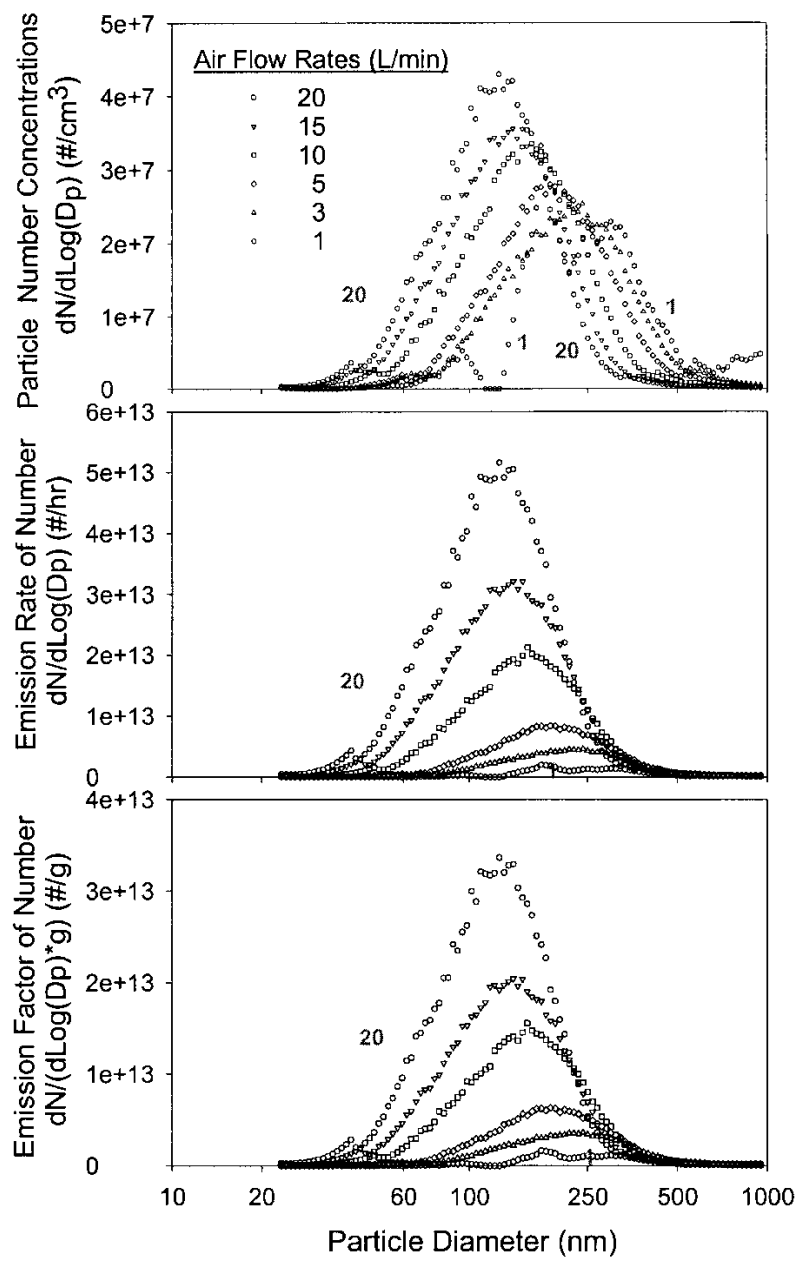

Figure 3. Aerosol number concentrations, emission rates and factors versus size of particles from burning incense at various air flow rates.

$\mathrm{mg} / \mathrm{hr}$; the emission factor was $5.0 \sim 55.7$ and $5.4 \sim 59.4 \mathrm{mg} / \mathrm{g}$, respectively. The emission rate and factor in this work differed a little from those of Lee and Jetter et al., perhaps because of differences of chemical composition, heating values of the incense and combustion conditions. Therefore, according to the aforementioned analysis, an air flow rate of $1 \mathrm{~L} / \mathrm{min}$ air flow rate minimized $\mathrm{PM}$ emission, to the benefit of the health of people who burn incense.

The temperature of the burning tip varied with the air flow rate as follows; $328.2^{\circ} \mathrm{C}$ $(1 \mathrm{~L} / \mathrm{min}), 452.9^{\circ} \mathrm{C}(3 \mathrm{~L} / \mathrm{min}), 431.7^{\circ} \mathrm{C}(5 \mathrm{~L} / \mathrm{min}), 253.0^{\circ} \mathrm{C}(10 \mathrm{~L} / \mathrm{min}), 210.1^{\circ} \mathrm{C}$ $(15 \mathrm{~L} / \mathrm{min})$ and $160.3^{\circ} \mathrm{C}(20 \mathrm{~L} / \mathrm{min})$ (Fig. 2). The concentrations of $\mathrm{CO}_{2}, \mathrm{CO}$ and TVOC, the emission rate and the emission factor increased with temperature from $328.2^{\circ} \mathrm{C}$ to $452.9^{\circ} \mathrm{C}$. The temperature and the concentrations of $\mathrm{CO}_{2}, \mathrm{CO}$ and 

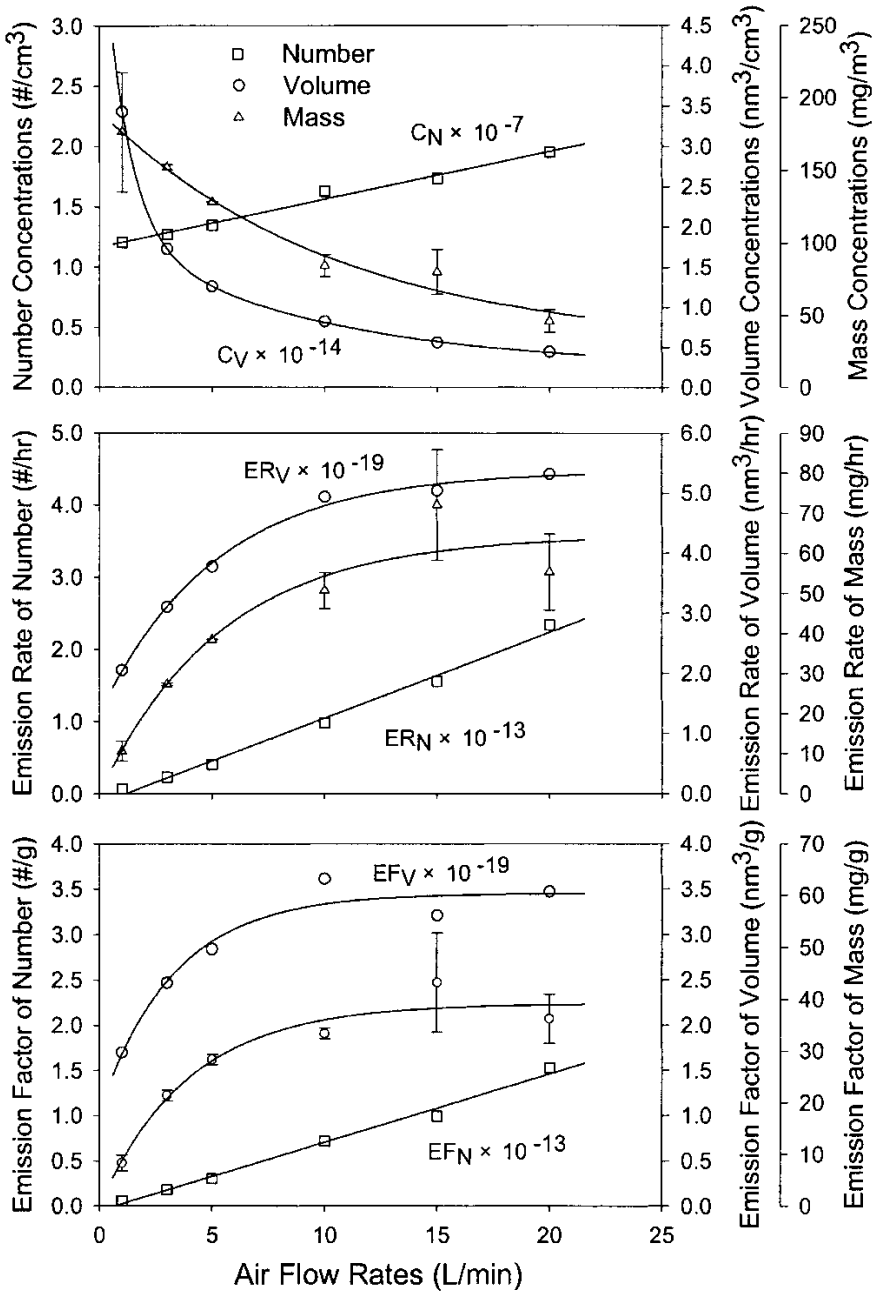

Figure 4. Aerosol number (volume and mass) emission concentrations, emission rates and factors from burning incense at various air flow rates (Bar: mean \pm standard deviation).

TVOC declined when the air flow rate was higher than $15 \mathrm{~L} / \mathrm{min}$ in Fig 5 . However, the emission rates of $\mathrm{CO}_{2}, \mathrm{CO}$ and TVOC steadily increased to stable levels, of between 1360 and 1379,415 , and between 77 and $78.9 \mathrm{mg} / \mathrm{hr}$, respectively with the air flow rate increasing. The emission factors of $\mathrm{CO}_{2}, \mathrm{CO}$ and TVOC also steadily increased to stable level between 866 and 900, between 264 and 271 , and between 49 and $51.4 \mathrm{mg} / \mathrm{g}$, respectively. The results showed that when the air flow rate was $1 \sim 20 \mathrm{~L} / \mathrm{min}$, the $\mathrm{CO}$ emission rate with $\mathrm{CV}_{\text {pooled }}=0.03 \quad(\mathrm{n}=2 \times 6)$ and the $\mathrm{CO}$ emission factor with $\mathrm{CV}_{\text {pooled }}=0.03(\mathrm{n}=2 \times 6)$ ranged from $48.7 \mathrm{mg} / \mathrm{hr} \quad(\mathrm{n}=2$, $\mathrm{CV}=0.06)$ to $415.4 \mathrm{mg} / \mathrm{hr}(\mathrm{n}=2, \mathrm{CV}=0.03)$ and from $40.2 \mathrm{mg} / \mathrm{g}(\mathrm{n}=2, \mathrm{CV}=0.06)$ to $271.1 \mathrm{mg} / \mathrm{g}(\mathrm{n}=2, \mathrm{CV}=0.03)$; that of $\mathrm{CO}_{2}$ with $\mathrm{CV}_{\text {pooled }}=0.05(\mathrm{n}=2 \times 6)$ ranged from $210.3 \mathrm{mg} / \mathrm{hr}(\mathrm{n}=2, \mathrm{CV}=0.09)$ to $1379.8 \mathrm{mg} / \mathrm{hr}(\mathrm{n}=2, \mathrm{CV}=0.02)$ and from 173.5 


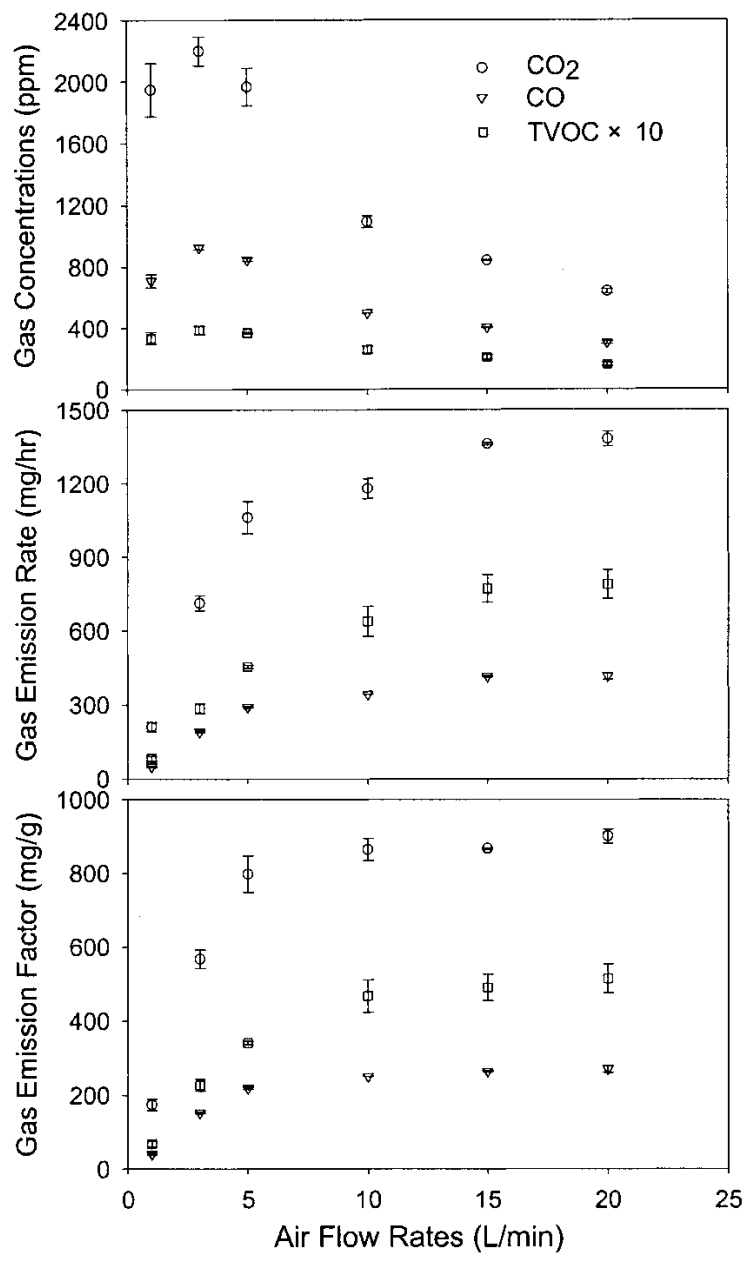

Figure 5. $\mathrm{CO}_{2}, \mathrm{CO}$, and TVOC emission concentrations, emission rates and factors from burning incense at various air flow rates (Bar: mean \pm standard deviation).

$\mathrm{mg} / \mathrm{g}(\mathrm{n}=2, \mathrm{CV}=0.09)$ to $900.3 \mathrm{mg} / \mathrm{g}(\mathrm{n}=2, \mathrm{CV}=0.03)$, and that of the TVOC with $\mathrm{CV}_{\text {pooled }}=0.08(\mathrm{n}=4 \times 6)$ was ranged from $8.2 \mathrm{mg} / \mathrm{hr}(\mathrm{n}=4, \mathrm{CV}=0.12)$ to $78.9 \mathrm{mg} / \mathrm{hr}$ $(\mathrm{n}=4, \mathrm{CV}=0.08)$ and from $6.8 \mathrm{mg} / \mathrm{g}(\mathrm{n}=4, \mathrm{CV}=0.12)$ to $51.5 \mathrm{mg} / \mathrm{g}(\mathrm{n}=4, \mathrm{CV}=0.08)$. Jetter et al. (1991) indicated that the emission rates of CO ranged from 159 to 227 $\mathrm{mg} / \mathrm{hr}$ and Löfroth et al. (1991) found that the emission factors of CO ranged from 180 to $220 \mathrm{mg} / \mathrm{g}$. Therefore, the range of emission rates obtained by Jetter et al. (1991) and the range of the emission factors obtained by Löfroth et al. (1991) include the range of emission rates and the emission factors of $\mathrm{CO}$ obtained herein. When the air flow rate was controlled at $1 \sim 20 \mathrm{~L} / \mathrm{min}$, the combustion efficiency with $\mathrm{CV}_{\text {pooled }}=0.01(\mathrm{n}=2 \times 6)$ declined drastically from $0.73(\mathrm{n}=2, \mathrm{CV}=0.008)$ to 0.67 ( $\mathrm{n}=2, \mathrm{CV}=0.004$ ) as the air flow rate increased, indicating that combustion was not complete at a high flow rate, although the mass transfer of oxygen 
molecules to the incense burning tip had increased because increasing the air flow rate may also increase the heat loss rate. The combustion was incomplete at a high air flow rate, so the emission rate and emission factor of the gas pollutant were high increased with air flow rate increasing. In conclusion, an air flow rate of under $1 \mathrm{~L} / \mathrm{min}$ minimized the emission rate and emission factors of gas pollutants from burning incense, and ensure more complete combustion, according to the characterization of gas emission.

Acknowledgments. We thank the National Science Council of the Republic of China, Taiwan, for financially supporting this research under Contract No. NSC-92-2320-B-002-157.

\section{REFERENCES}

Maclennan R, Costa JD, Day NE, Law CH, Ng YK, Shanmugaratnam K (1977) Risk factors for lung cancer in Singapore Chinese, A population with high female incidence rate. Int J Cancer 20:854-860.

Lowengard RA, Peters JM, Cinioni C, Buckley J, Bernstein L, Preston-Martin S, Edward R (1987) Childhood leukemia and parent's occupation and home exposure. J Natl Cancer Inst 79(1):39-46.

Preston-Martin S, Yu MC, Benten B, Henderson BE (1982) N-nitroso compounds and childhood brain tumors: A case-control study. Cancer Res 42:5240-5245.

Sato S, Makino R, Takahashi Y, Sugimura T, Miyazaki T (1980) Mutagenicity of smoke condensates from joss sticks. Mut Res 77:31-36.

Rasmussen RE (1987) Mutagenic activity of incense smoke in Salmonella typhimurium. Bull Environ Contam Toxicol 38:827-833.

Löfroth G, Stensman C, Margareta BS (1991) Indoor sources of mutagenic aerosol particulate matter: smoking, cooking and incense burning. Mut Res 261:21-28.

Chang HL, Kuo ML, Lee JK (1997) Mutagenic activity of incense smoke in comparison to formaldehyde and acetaldehyde in Salmonella typhimurium TA102. Bull Environ Contam Toxicol 58:394-401.

Schoental R, Gibbard S (1967) Carcinogens in Chinese incense smoke. Nature 216-612.

Lin JM, Wang LH (1994) Gaseous aliphatic aldehydes in Chinese incense smoke. Bull Environ Contam Toxicol 53:374-481.

Lin JM, Tang CS (1994) Characterization and aldehyde content of particulates in Chinese incense smoke. Bull Environ Contam Toxicol 53:895-901.

Lin JM, Lee JK (1998) Vaporous and particulate-bound polycyclic aromatic hydrocarbons in Chinese incense smoke. Toxicol Environ Chem 67:105-113.

Wang JH, Chao CYH, Kong W (2003) Experimental study and asymptotic analysis of horizontally forced forward smoldering combustion. Combust Flame 135:405-419.

Jetter JJ, Guo Z, Mcbrian JA, Flynn MR (2002) Characterization of emissions from burning incense. Sci Tot Environ 295:51-67.

Lee SC, Wang B (2004) Characteristics of incense of air pollutants from burning of incense in a large environmental chamber. Atmos Environ 38:941-951. 